\title{
Mechanical Properties of Concrete Slabs Reinforced with Recycled Steel Fibers from Post-Consumer Tires in Bogotá, Colombia*
}

Julián Carrillo - Carlos Díaz ${ }^{\mathrm{b}}$

\begin{abstract}
Millions of post-consumer tires are not adequately disposed of each year, and thus, are producing an enormous environmental problem in the world. This environmental impact may be reduced when assessing this material as an alternative reinforcement for concrete. It is widely known that the toughness of steel fiber-reinforced concrete is suitably assessed by energy absorption tests on slabs. The purpose of this paper is to show and discuss the results of a research aimed at assessing the mechanical response of concrete slabs reinforced with recycled steel fibers from post-consumer tires in Bogotá, Colombia. The testing program of the study comprised 31 axial compression tests on cylinders, and 15 bending tests on concrete slabs reinforced with nominal dosages of 15,30 , and $60 \mathrm{~kg} / \mathrm{m}^{3}$ of industrial steel fibers or recycled fibers obtained from post-consumer tires. Based on the measured response, preliminary design equations are proposed to estimate the mechanical properties of concrete reinforced with recycled steel fibers.
\end{abstract}

Keywords: Steel fiber-reinforced concrete; waste tires; recycled steel fiber; slabs; flexural performance; toughness; energy absorption

Received: 18/12/2019 Acccepted: 17/04/2020

Avilable online: 09/12/2020

How to cite:J. Carrillo and C. Díaz, "Mechanical Properties of Concrete Slabs Reinforced with Recycled Steel Fibers from Post-Consumer Tires in Bogotá, Colombia", Cien.Ing.Neogranadina, vol. 30, no. 2, Jul 2020.

* Research article.

a Full professor, Department of Civil Engineering, Universidad Militar Nueva Granada, UMNG. Bogotá, Colombia. E-mail: julian.carrillo@unimilitar.edu.co. ORCID: http://orcid.org/0000-0002-8274-5414

b Research Assistant, Department of Civil Engineering, Universidad Militar Nueva Granada, UMNG. Bogotá, Colombia. E-mail: estructuras.sismica@unimilitar.edu.co. ORCID: http://orcid.org/0000-0002-9562-745X 


\section{Propiedades mecánicas de las losas de concreto reforzadas con fibras de acero recicladas provenientes de llantas usadas en Bogotá, Colombia}

Resumen: cada año, millones de llantas usadas no se desechan de forma adecuada y, por tanto, generan un enorme problema ambiental en el mundo que se podría reducir a partir de la evaluación de este material como alternativa de refuerzo para el concreto. Es bien sabido que la tenacidad del concreto reforzado con fibras de acero se puede evaluar a partir del ensayo de absorción de energía en losas. El objetivo de este artículo es mostrar y analizar los resultados de una investigación enfocada en evaluar la respuesta mecánica de las losas de concreto reforzado con fibras recicladas de acero obtenidas de llantas usadas en Bogotá, Colombia. El programa experimental del estudio incluye 31 ensayos de compresión axial de cilindros y 15 ensayos a flexión en losas de concreto reforzadas utilizando dosificaciones nominales de $15 \mathrm{~kg} / \mathrm{m}^{3}, 30 \mathrm{~kg} / \mathrm{m}^{3}$ y $60 \mathrm{~kg} / \mathrm{m}^{3}$ de fibras de acero industrial o reciclada obtenidas de llantas usadas. A partir de la respuesta medida, se proponen ecuaciones preliminares de diseño para estimar las propiedades mecánicas de las losas de concreto reforzadas con fibras recicladas de acero.

Palabras clave: concreto reforzado con fibras; Ilantas de desecho; fibra recicladas de acero; losas; desempeño a flexión; tenacidad; absorción de energía 


\section{Introduction}

Most post-consumer tires in the world are not adequately disposed of, accumulated in public spaces of cities, and, sometimes, improperly burned in the open field. This improper handling could cause serious health issues to the population. The use of recycled materials from waste tires in construction materials has been evaluated in the last years as the perfect opportunity for offering practical solutions to waste materials [1]. Through a recycling process, all the raw materials of tires (steel, rubber, or textiles) could be employed in the manufacture of sustainable construction materials. For instance, tire rubber has been reused massively in normal- and high-strength concretes [2], asphalt, playground surfaces, synthetic sports fields, and unique coverings [1].

In the same way, steel fibers recovered from recycled post-consumer tires have been used in concrete pavements [3] or high-performance cementitious composites such as slurry infiltrated fiber concrete [4]. The main methods for extracting steel, textile, and rubber from tires are thermolysis, pyrolysis, incineration, and crushing, being the latter the most widely used by the tire recycling industry. It consists in reducing the tire size to small pieces to separate the rubber from the steel and the textile.

In terms of the mechanical properties of recycled steel fiber-reinforced concrete, Aiello ET AL. [5], Rossli and Ibrahim [6], and Sengul [7] confirmed that adding recycled steel fibers from tires to concrete improves crack resistance, compressive strength, bending strength, tensile strength, and fracture energy of concrete. Centonze et al. [8] observed that load-deflection results from concrete slabs reinforced with recycled steel fibers were comparable to those obtained from concrete reinforced with industrial fibers, which confirms the effectiveness of recycled steel fibers. When combining recycled and industrial fibers, Graeff et al. [3] argued that this hybrid fiber (industrial and recycled) could lead to a reduction of pavement slab thickness by up to $26 \%$ since the fatigue strength increases. However, Centonze et al. [9] observed that the existing bonding between concrete and reinforcing bars does not significantly change with the addition of recycled steel fibers. Also, Zamanzadeh ET AL. [10] stated that the deflection achieved using specimens reinforced with industrial fibers was more significant than that developed by specimens reinforced with recycled fibers. This result confirmed that the "bridge effect" exerted by industrial fibers on the surface of the crack of the specimen was more significant than the effect caused by recycled fibers.

This environmental impact of post-consumer tires may be reduced when assessing this material as an alternative reinforcement for concrete. It is widely known that the toughness of steel fiber-reinforced concrete is suitably assessed by energy absorption tests on slabs. The purpose of this paper is to show and discuss the results of a research aimed at assessing the mechanical response of concrete slabs reinforced with recycled steel fibers from post-consumer tires in Bogotá, Colombia. The testing program of the study comprised 31 axial compression tests on cylinders and 15 bending tests on concrete slabs reinforced with nominal fiber dosages of $15 \mathrm{~kg} / \mathrm{m}^{3}, 30 \mathrm{~kg} /$ $\mathrm{m}^{3}$, and $60 \mathrm{~kg} / \mathrm{m}^{3}$ of industrial steel fibers or steel fibers obtained from post-consumer tires. Based on the measured response, preliminary design equations are proposed to estimate the mechanical properties of concrete slabs reinforced with recycled steel fibers. The results of this study intend to demonstrate whether this type of material can be considered as a local alternative for the production of structural and non-structural fiber-reinforced concrete elements. They are also expected to increase the reliability of the use of steel fibers from tire recycling as a reinforcement for concrete.

\section{Experimental Program}

The experimental program comprised tests on standard cylinders and slabs made of plain concrete, concrete reinforced with recycled steel fibers, and concrete reinforced with industrial steel fibers. The specified compressive strength of concrete was $21 \mathrm{MPa}$, the maximum size of the aggregate was $38.1 \mathrm{~mm}$, and the specified slump of concrete was $178 \mathrm{~mm}$. The values of the nominal 
properties of concrete are characteristic of those used for the construction of walls for low-rise housing. Concrete was prepared and provided by a ready-mix company. The steel fibers (recycled and industrial) were mixed in the laboratory using mechanical concrete mixers and a concrete truck mixer.

\section{Description of specimens}

Table 1 describes the two types of fibers and the dosages used, where $D_{f^{\text {nominal }}}$ is the nominal dosage of the fiber in $\mathrm{kg} / \mathrm{m}^{3}$, and $V_{f}$ is the volume fraction computed as the ratio between Df and steel density $\left(7850 \mathrm{~kg} / \mathrm{m}^{3}\right)$ as a percentage. The parameter $\% D_{f^{\prime} \text { in }}$ is related to the ratio between $D_{f \text { nominal }}$ and the minimum dosage specified by the ACI-318 [11] and the NSR-10 [12] to replace the minimum shear reinforcement provided by conventional steel in beams $\left(D_{f-\text { min }}=60 \mathrm{~kg} / \mathrm{m}^{3}\right)$. The aspect ratio $\left(l_{f} / d_{f}\right)$ of fibers is computed as the ratio between the length $\left(l_{f}\right)$ and diameter $\left(d_{f}\right)$ of the fiber. This paper describes the procedure used to obtain the recycled steel fibers and their relevant geometric characterization.

The experimental program included tests of compressive strength, elasticity modulus, and bending of concrete slabs to identify the mechanical properties of concrete reinforced with industrial steel fibers and steel fibers recycled from tires. Table 2 shows the number of specimens for plain concrete (PC), industrial steel fiber-reinforced concrete (ISFRC), and recycled steel fiber-reinforced concrete (RSFRC). In summary, the experimental program included 31 cylinders having $150 \mathrm{~mm}$ diameter and $300 \mathrm{~mm}$ height, and 15 slabs measuring $100 \times 600 \times 600 \mathrm{~mm}$. It was defined that the PC mix was the control mixture.

Table 1. Variables of the Study

\begin{tabular}{|c|c|c|c|c|}
\hline Variable & \multicolumn{4}{|l|}{ Description } \\
\hline \multirow{4}{*}{$\begin{array}{l}\text { Industrial steel } \\
\text { fibers }\end{array}$} & Hook type: & \multicolumn{3}{|c|}{ Hooked-end } \\
\hline & Length, $I_{f}, \mathrm{~mm}$ : & \multicolumn{3}{|l|}{50} \\
\hline & Diameter, $d_{f}, \mathrm{~mm}$ : & \multicolumn{3}{|l|}{1.05} \\
\hline & Aspect ratio, $I_{f} / d_{f}$ : & \multicolumn{3}{|l|}{48} \\
\hline \multirow{5}{*}{$\begin{array}{l}\text { Recycled steel } \\
\text { fibers }\end{array}$} & Reference: & \multicolumn{3}{|c|}{ Fiber recycled from used tires } \\
\hline & Hook type: & \multicolumn{3}{|c|}{ No hook } \\
\hline & Average equivalent length, $I_{f}, \mathrm{~mm}$ : & \multicolumn{3}{|l|}{31.1} \\
\hline & Average diameter, $d_{f}, \mathrm{~mm}$ : & \multicolumn{3}{|l|}{0.23} \\
\hline & Average aspect ratio, $I_{f} / d_{f}:$ & \multicolumn{3}{|c|}{144.3} \\
\hline \multirow{3}{*}{$\begin{array}{l}\text { Dosages for both } \\
\text { types of fibers }\end{array}$} & $\% D_{f-\min } \%$ & 25 & 50 & 100 \\
\hline & $D_{f-\text { nominal, }} \mathrm{kg} / \mathrm{m}^{3}$ : & 15 & 30 & 60 \\
\hline & Volume fraction, $V_{f} \%$ : & 0.19 & 0.38 & 0.76 \\
\hline
\end{tabular}

Source: Own elaboration. 
Table 2. Testing Program

\begin{tabular}{|c|c|c|c|c|c|c|c|}
\hline \multirow[t]{3}{*}{ Testing type } & \multicolumn{7}{|c|}{$D_{f-\text { nominalı }}, \mathbf{k g} / \mathbf{m}^{\mathbf{3}}$} \\
\hline & \multicolumn{2}{|c|}{ PC } & \multicolumn{2}{|c|}{ ISFRC } & \multicolumn{3}{|c|}{ RSFRC } \\
\hline & 0 & 15 & 30 & 60 & 15 & 30 & 60 \\
\hline Compressive strength & 1 & 2 & 2 & 2 & 1 & 1 & 1 \\
\hline Elasticity modulus & 3 & 3 & 3 & 3 & 3 & 3 & 3 \\
\hline Flexural performance of slabs & 2 & 2 & 3 & 2 & 2 & 2 & 2 \\
\hline
\end{tabular}

Source: Own elaboration.

\section{Preparation of specimens}

Two mechanical concrete mixers were used to mix the concrete with recycled steel fibers. The fiber was untangled manually and then introduced into the mixer to avoid clusters of recycled steel fibers. Despite this procedure, the irregular and varied shape of the recycled fibers caused some small clusters of fibers when casting the specimens. On the other hand, industrial steel fibers were directly mixed at the ready-mix company.
In the case of the industrial fibers, no fiber clusters were observed [13].

\section{Test setup}

The tests of elasticity modulus and energy absorption of fiber reinforced concrete slabs were carried out per ASTM standard C469 [14] and European standard 14488-5 [15], respectively. The setup of the tests used to characterize the mechanical response of the fiber reinforced concrete (FRC) is shown in Fig. 1.
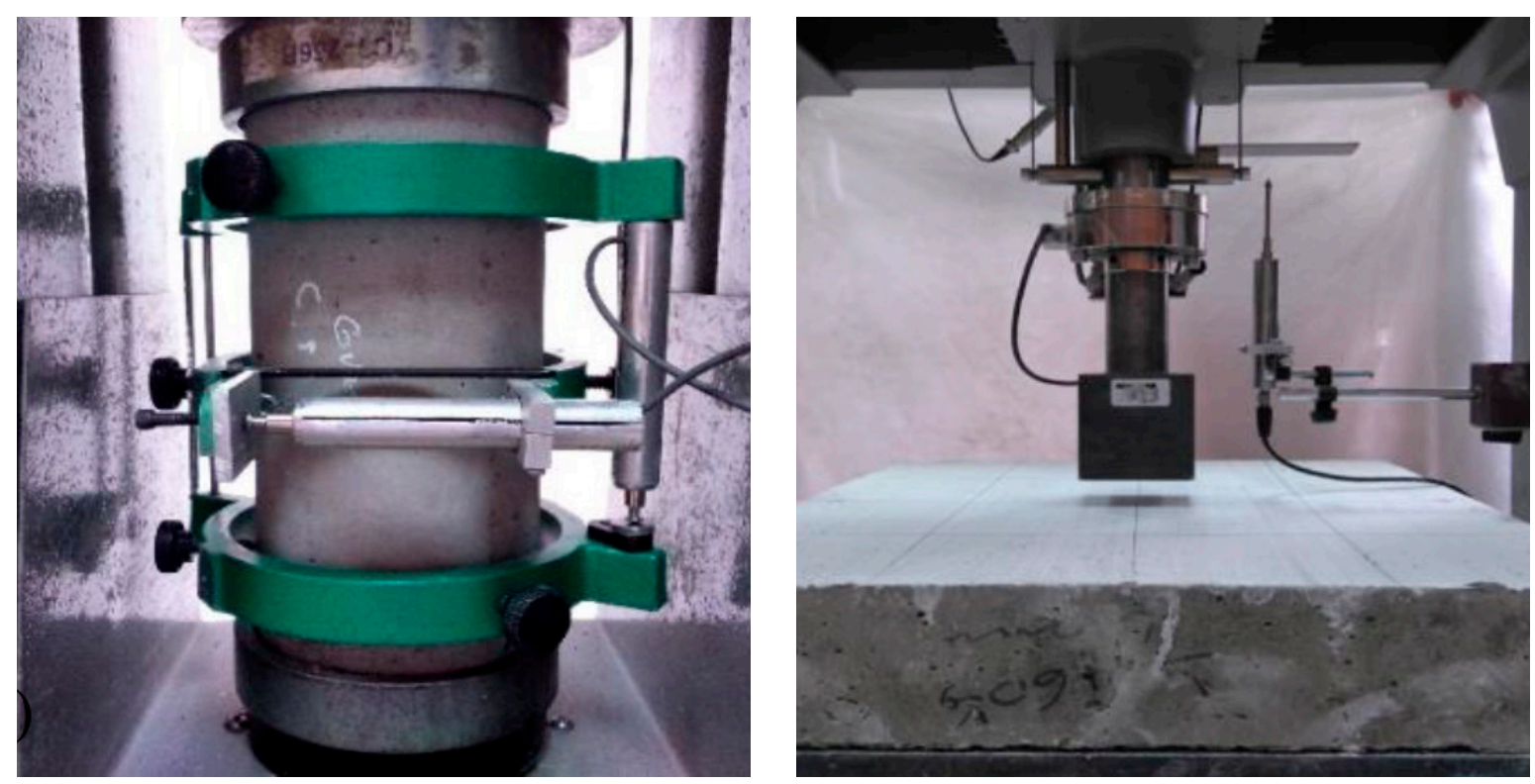

Fig. 1. Test setup: (a) elasticity modulus and Poisson's ratio, (b) flexural performance of slabs.

Source: Own elaboration. 


\section{Results and Discussion}

Test results are discussed in this section. Test results of the compressive strength and flexural performance of slabs are then compared with results reported in the technical literature.

\section{Geometric characterization of recycled steel fibers}

The diameter and length of the steel fibers recycled from tires depend on the method of extraction. As the rubber in the recycled steel fiber decreases, the bonding strength between concrete and fibers increases. So, it was necessary to separate fibers from bonded rubber, rubber granules, and longer fibers by sieving the material through a no. $4(4.75 \mathrm{~mm})$ mesh. To eliminate the rubber excess of the material, a powerful magnet was used to separate the steel from the rubber granules featuring a diameter smaller than the no. 4 sieve. A sample size of 1,067 recycled steel fibers was determined using statistical analysis. The statistical analysis of the measured geometry was expressed in terms of average $(X)$, coefficient of variation $(\mathrm{CV})$, and minimum and maximum values. The recycled steel fibers are irregular and include fibers having a wide range of lengths. The equivalent length considered here corresponds to the distance between the opposite ends of the fiber. The results of the statistical analysis of the average equivalent length $\left(l_{f}\right)$ are shown in Table 3.

Table 3. Statistical Analysis of the Geometry of Recycled Fibers

\begin{tabular}{llll}
$\begin{array}{l}\text { Statistical } \\
\text { Parameter }\end{array}$ & $l_{f}, \mathrm{~mm}$ & $d_{f,} \mathrm{~mm}$ & $I_{f} / d_{f}$ \\
$X$ & 31.1 & 0.23 & 144.3 \\
CV, \% & 50.4 & 28.1 & 57.0 \\
Minimum & 9.1 & 0.08 & 34.7 \\
Maximum & 110.5 & 0.38 & 529.3 \\
\hline
\end{tabular}

Like the equivalent length, the diameter of recycled steel fibers varies in each fiber, and even along the fiber length. In determining the fiber diameter, it was necessary to take three measurements due to a lack of uniformity along the fiber length: two at the opposite ends of the fiber, and another one in the middle. This study relates the diameter of the fiber to the average of the three measurements taken; the results are shown in Table 3. The measured diameters are similar to those obtained in other studies; for example, Centonze ET AL. [8] reported an average diameter of $0.24 \mathrm{~mm}$, and Aiello et al. [5] obtained a value of $0.26 \mathrm{~mm}$.

The aspect ratio of recycled fibers was computed as the ratio between each sample fiber's equivalent length and average diameter. The statistical parameters for the geometric characteristics of the fibers in the sample are also shown in Table 3. The steel fibers recycled from used tires feature small diameter sizes and relatively typical lengths, which causes high aspect ratios in some cases. Section 2.2.1 of ACI 544.1 [16] states, for example, that the fiber's bending capacity is directly related to its aspect ratio, and thus this standard establishes typical aspect ratio values between 20 and 100 for the industrial steel fibers. The calculated ratios used in this research (144.3) are higher than the values recommended by ACI 544.1.

\section{Compressive behavior}

Table 4 summarizes the mechanical properties of PC, ISFRC, and RSFRC under compressive stresses. It also shows the measured dosages of fibers used for concrete reinforcement. 
Table 4. Compressive Mechanical Properties of Concrete

\begin{tabular}{|c|c|c|c|c|c|c|c|c|}
\hline Type of Concrete & \multirow[b]{2}{*}{$\begin{array}{l}\text { Statistical } \\
\text { Parameter }\end{array}$} & \multirow{2}{*}{$\begin{array}{l}\mathrm{PC} \\
0\end{array}$} & ISFRC & \multicolumn{5}{|c|}{ RSFRC } \\
\hline$D_{f \text {-measured }}, \mathrm{kg} / \mathrm{m}^{3}$ & & & 12.7 & 31.5 & 65.2 & 18.6 & 34.0 & 65.1 \\
\hline$V_{f}, \%$ & & 0 & 0.16 & 0.40 & 0.83 & 0.24 & 0.43 & 0.83 \\
\hline \multirow{2}{*}{$f_{c}^{\prime}, \mathrm{MPa}$} & $X$ & 42.3 & 41.7 & 40.0 & 32.0 & 41.9 & 42.1 & 41.6 \\
\hline & $C V, \%$ & 8.3 & 2.5 & 5.2 & 12.0 & 6.6 & 2.0 & 0.9 \\
\hline \multirow{2}{*}{$E_{c} \mathrm{MPa}$} & $X$ & 24,039 & 22,185 & 21,983 & 19,900 & 24,688 & 22446 & 23142 \\
\hline & $C V, \%$ & 17.3 & 0.6 & 2.1 & 2.9 & 3.2 & 2.5 & 1.2 \\
\hline
\end{tabular}

Source: Own elaboration.

\section{Flexural performance from slab tests}

Fig. 2 shows the final cracking patterns of the PC slabs and the steel fiber reinforced slabs using a fiber dosage close to $65 \mathrm{~kg} / \mathrm{m}^{3}$. The cracking patterns are similar for the two types of fibers, where the cracks extend from the center of the specimen to the corners and sides. This crack pattern was also reported by Centonze ET AL. [8] for dosages of recycled and industrial fibers of $31.8 \mathrm{~kg} / \mathrm{m}^{3}$ and $34.8 \mathrm{~kg} / \mathrm{m}^{3}$, respectively.

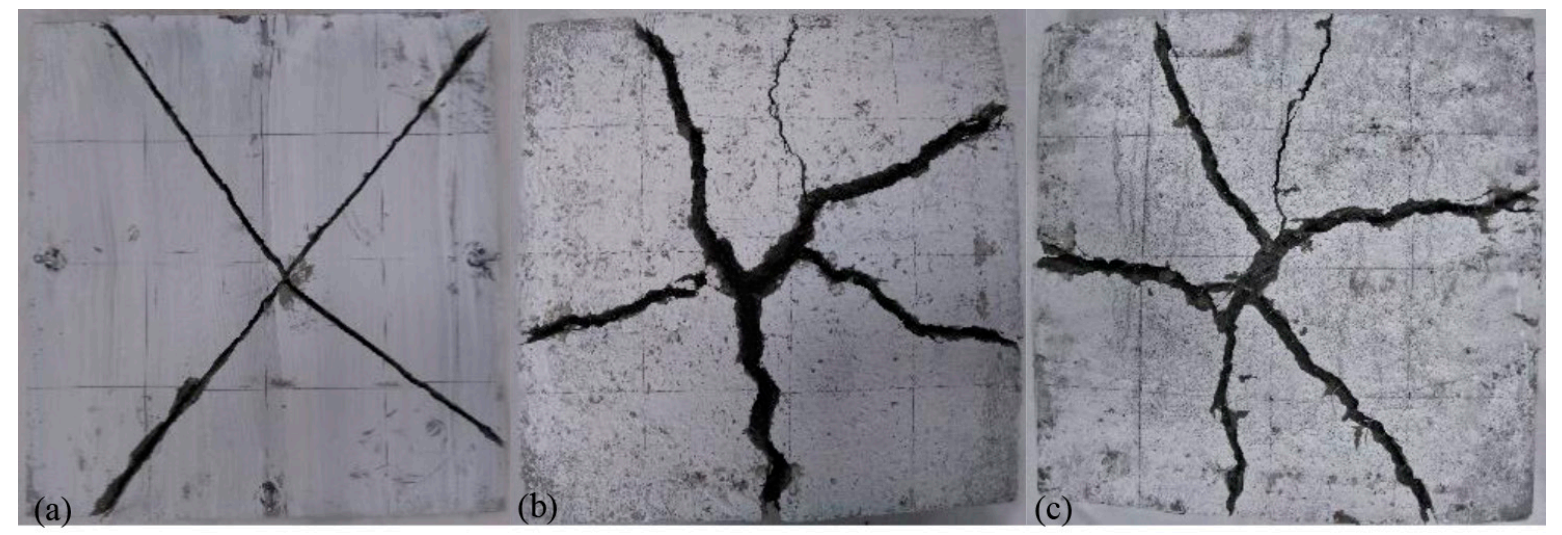

Fig. 2. Final cracking patterns from bending tests on slabs: (a) PC, (b) RSFRC $D_{f}=65.1 \mathrm{~kg} / \mathrm{m}^{3}$, (c) ISFRC $D f=65.2 \mathrm{~kg} / \mathrm{m}^{3}$.

Source: Own elaboration. 
Fig. 3 shows the load-deflection curves obtained from the tests carried out on PC, RSFRC, and ISFRC slabs. The deflections obtained are vertical displacements in the center of the slab; that is, the point at which the load was applied. The basic mechanical parameters to analyze the bending behavior of steel fiber-reinforced concrete slabs are maximum load $\left(\mathrm{P}_{\mathrm{ma}} \mathrm{x}\right)$, the deflection associated with $\mathrm{P}_{\max }\left(\delta_{\max }\right)$, ultimate load $\left(\mathrm{P}_{\mathrm{u}}\right)$, and the deflection associated with $\mathrm{P}_{\mathrm{u}}\left(\delta_{\mathrm{u}}\right)$.
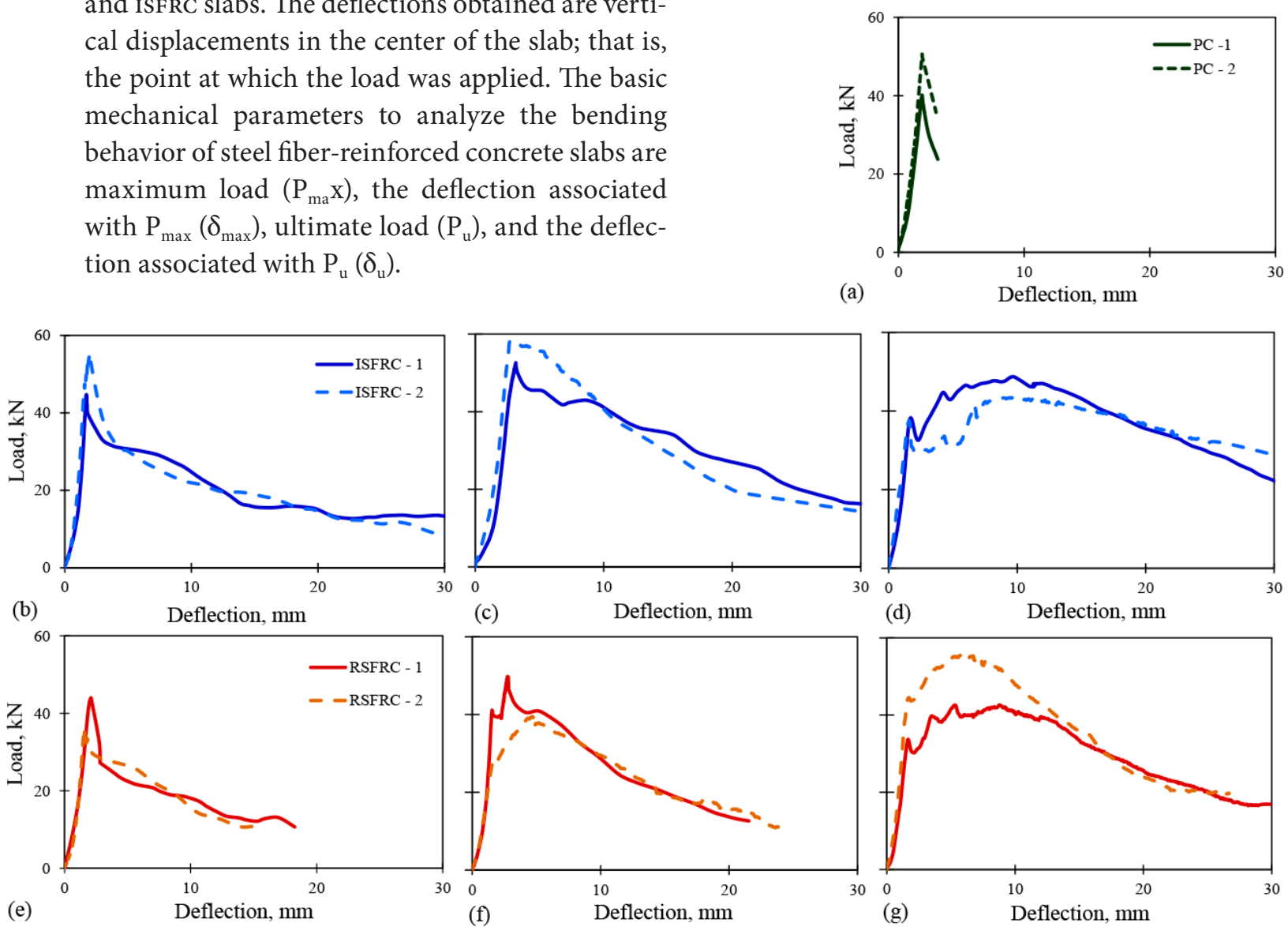
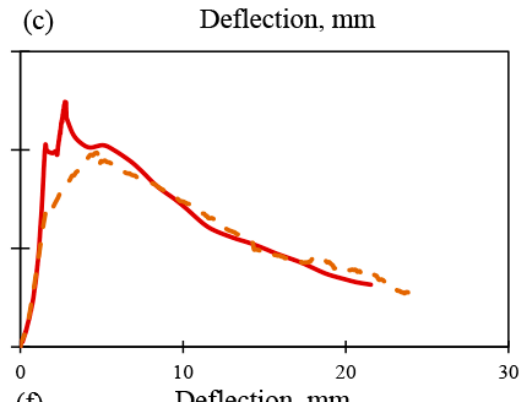

(f)

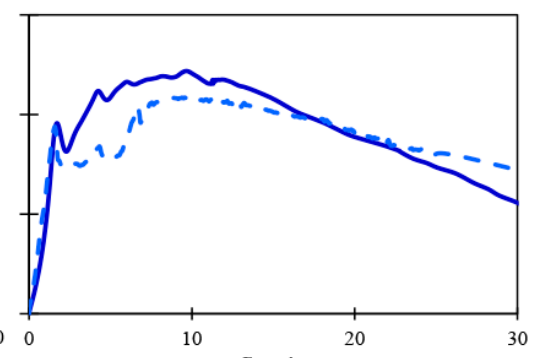

(d)

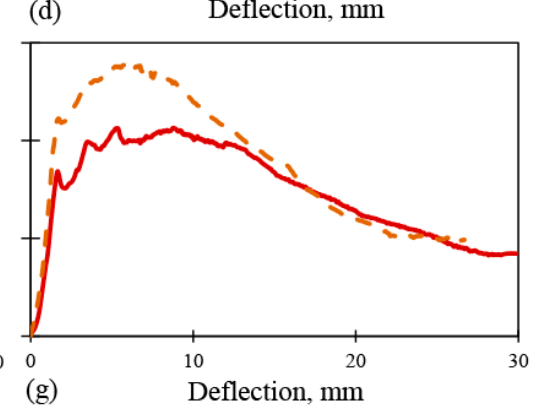

(g)

Fig. 3. Load-deflection curves from bending tests on slabs for different values of $D_{f}$ in $\mathrm{kg} / \mathrm{m}^{3}$, PC: (a) 0 , ISFRC: (b) 12.7, (c) 31.5, (d) 65.2, RSFRC: (e) 18.6, (f) 34.0, (g) 65.1.

Source: Own elaboration.

The load-deflection curves in Fig. 3 demonstrated that both fibers contribute to a better structural performance of concrete slabs. For example, for dosages of recycled and industrial fibers near $65 \mathrm{~kg} / \mathrm{m}^{3}$, Figs. 3d and $3 \mathrm{~g}$ show that both types of fibers allow concrete to increase their strength after exceeding the first peak point. However, Figs. $3 \mathrm{~d}$ and $3 \mathrm{~g}$ show that industrial steel fibers provide concrete with higher capacity to support deflections compared to recycled fibers. For example, ISFRC showed a deflection of up to $43 \mathrm{~mm}$ for a dosage of $65.2 \mathrm{~kg} / \mathrm{m}^{3}$, while RSFRC reached a 30 mm deflection for a dosage of $65.1 \mathrm{~kg} / \mathrm{m}^{3}$. A similar trend was observed in concretes with other dosages; this trend can be attributed to the hooks of the industrial steel fibers.

Table 5 summarizes the basic mechanical parameters of steel fiber-reinforced concrete slabs. Results in the table are related to the average of the two specimens prepared for each dosage. There is no broad spread of data (CV less than $18.7 \%$ ), except for some parameters such as $\mathrm{P}_{\mathrm{u}}$ in the industrial fiber and $\delta_{\max }$ in the recycled fiber, where $C V$ values reach up to $37 \%$. 
Table 5. Flexural Mechanical Properties of Concrete Slabs

\begin{tabular}{|c|c|c|c|c|c|c|c|c|}
\hline $\begin{array}{l}\text { Type of } \\
\text { Concrete }\end{array}$ & \multirow{2}{*}{$\begin{array}{l}\text { Statistical } \\
\text { Parameter }\end{array}$} & PC & \multicolumn{3}{|l|}{ ISFRC } & \multicolumn{2}{|l|}{ RSFRC } & \multirow[b]{2}{*}{65.1} \\
\hline $\begin{array}{l}D_{f-\text { measured }} \\
\mathrm{kg} / \mathrm{m}^{3} \\
\mathrm{Vf}, \%\end{array}$ & & 0 & 12.7 & 31.5 & 65.2 & 18.6 & 34.0 & \\
\hline \multirow{2}{*}{$P_{\max }, \mathrm{kN}$} & $X$ & 45.4 & 49.9 & 55.4 & 46.1 & 39.7 & 44.6 & 49.1 \\
\hline & $C V, \%$ & 16.3 & 14.6 & 7.1 & 8.1 & 15.1 & 16.4 & 18.7 \\
\hline \multirow{2}{*}{$\delta_{\max }, \mathrm{mm}$} & $X$ & 1.8 & 1.8 & 2.9 & 9.8 & 1.8 & 3.7 & 7.4 \\
\hline & $C V, \%$ & 0.18 & 9.0 & 11.1 & 2.1 & 20.7 & 37.0 & 25.7 \\
\hline \multirow{2}{*}{$P_{u}, \mathrm{kN}$} & $x$ & 29.8 & 11.4 & 14.1 & 16.6 & 10.9 & 11.8 & 18.3 \\
\hline & $C V, \%$ & 28.6 & 22.2 & 11.2 & 27.8 & 3.0 & 10.5 & 10.9 \\
\hline \multirow{2}{*}{$\delta_{u}, \mathrm{~mm}$} & $x$ & 3.1 & 32.9 & 37.2 & 41.7 & 17.0 & 22.7 & 28.3 \\
\hline & $C V, \%$ & 3.3 & 8.7 & 5.6 & 5.2 & 10.8 & 7.2 & 8.0 \\
\hline
\end{tabular}

Source: Own elaboration.

Fig. 4 shows the relationship between the main flexural properties of concrete slabs and $V_{f} \times\left(l_{f} / d_{f}\right)$ for recycled and industrial fibers, as well as the trends of the measured properties of ISFRC and RSFRC. A linear regression analysis was also carried out for computing the equations and their relevant $r$ coefficients. The $r$ coefficient calculates the degree of intensity of the relationship between the properties measured and the ones calculated.

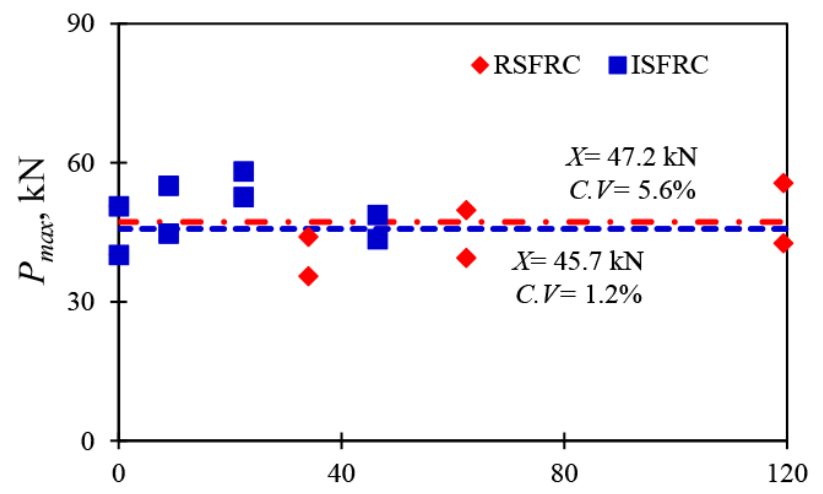

(a)

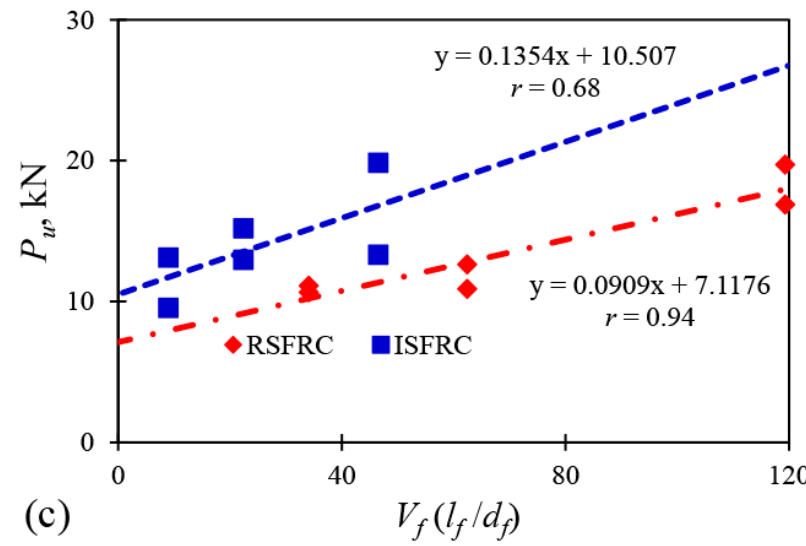

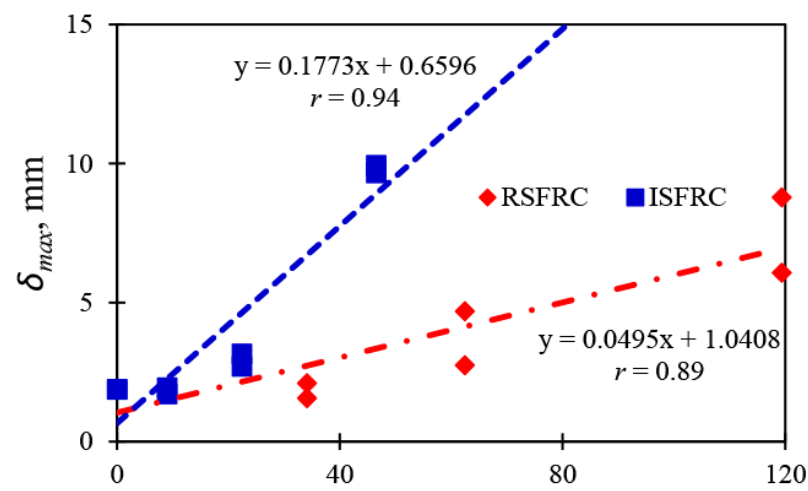

(b)

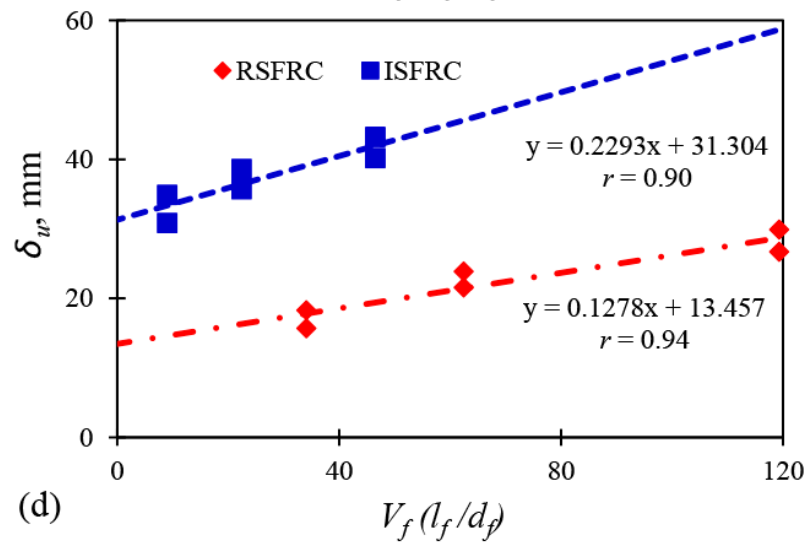

Fig. 4. Trends of the bending mechanical properties of PC, RSFRC, and ISFRC slabs: (a) $P_{\max }{ }^{1}$, (b) $\delta_{\max ^{1}}$, (c) $P_{\mathrm{u}^{1}}$, (d) $\delta_{\mathrm{u}^{1}}$. Source: Own elaboration. 
As observed in Fig. 4a, $P_{\max }$ for the two types of fibers remains constant upon increasing the dosage of fibers; however, the $P_{\max }$ for RSFRC is slightly higher than that of ISFRC $(47.2 \mathrm{kN}$ and $45.7 \mathrm{kN}$, respectively). On the other hand, Fig. $4 \mathrm{~b}$ shows that $\delta$ max increases as $V_{f} \times\left(l_{f} / d_{f}\right)$ augments for both types of fibers. Centonze ET AL. [8] reported deflections of $3.52 \mathrm{~mm}$ corresponding to the maximum load of RSFRC with a dosage of $34.0 \mathrm{~kg} / \mathrm{m}^{3}$ of recycled fibers; that is, this deflection was only $5 \%$ lower than that obtained in the bending tests reported herein.

Fig. $4 \mathrm{c}$ shows that the ultimate load $\left(P_{u}\right)$ increases as the parameter $V_{f} \times\left(l_{f} / d_{f}\right)$ augments; however, the ultimate load values are higher for ISFRC. Carrillo and Silva [17] have also reported this increase; for instance, they stated that $P_{u}$ increases with the dosage of industrial fibers. This trend was attributed to the fact that when the amount of fibers increases, the concrete has higher deflections that elevate the residual strength. On the other hand, Fig. $4 d$ shows the capacity of SFRC to withstand ultimate deflections, $\delta_{u}$ increases as $V_{f} \times$ $\left(l_{f} / d_{f}\right)$ arguments for both types of fibers, although the $\delta u$ values for industrial fibers were higher than those of recycled fibers.

Fig. 5 shows the relationship between the energy and the deflection measured at the center of RSFRC and ISFRC slabs. As observed, the energy absorption increases when increasing the content of recycled and industrial fibers. This increment is due to the ability of fibers of hooking micro-cracks, avoiding significant crack widths before the failure occurs by pulling out the fibers [17]. The ISFRC toughness for all the fiber dosages is always higher than that of the recycled fiber, which indicates that, even though the RSFRC from tires contributes to the better performance of concrete, recycled steel fibers are not able to replace the contribution made by industrial steel fibers. Centonze et al. [8] observed a $22 \%$ drop in the energy absorption capacity of the RSFRC with a $D_{f}$ of $31.8 \mathrm{~kg} / \mathrm{m}^{3}$ when compared to ISFRC with a $D_{f}$ of $34.8 \mathrm{~kg} / \mathrm{m}^{3}$. In the study reported herein, the energy drop was $45 \%$ for dosages of $34.0 \mathrm{~kg} / \mathrm{m}^{3}$ of recycled fiber and $31.5 \mathrm{~kg} / \mathrm{m}^{3}$ of industrial fibers, which are similar to those studied by Centonze et al. [8]; this reduction is $23 \%$ greater than that observed by those autors.
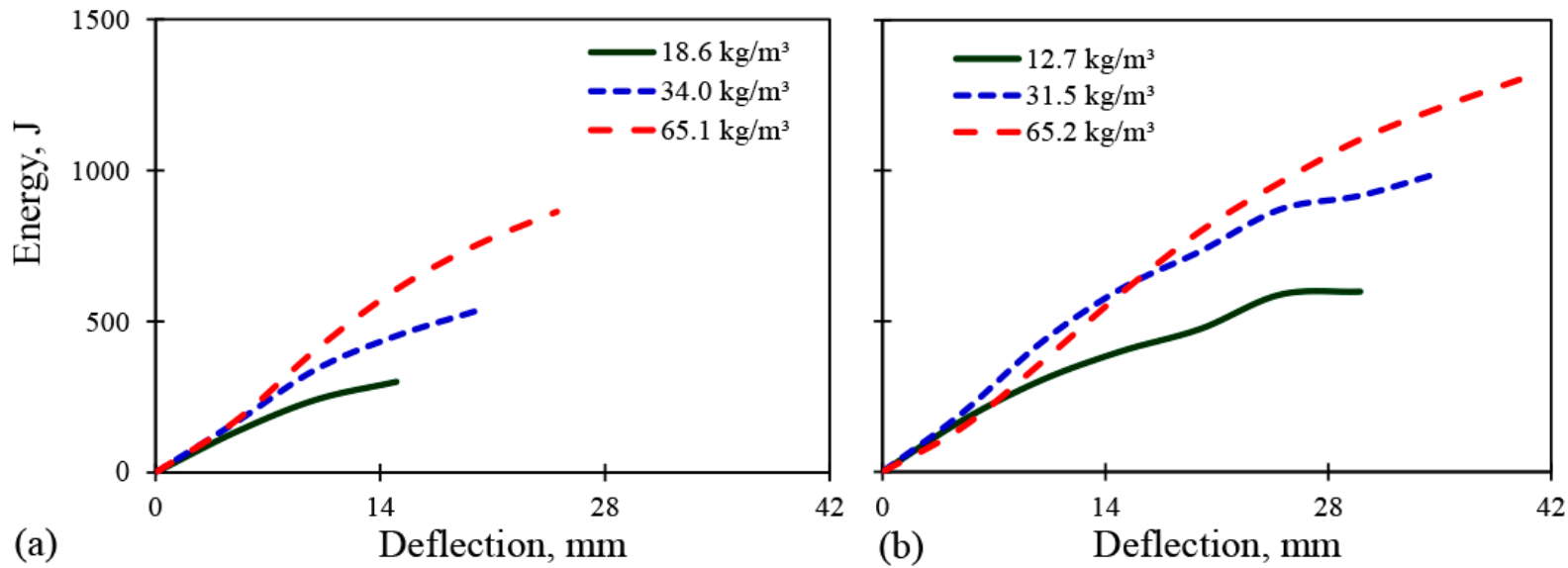

Fig. 5. Energy-deflection curves from slab bending tests: (a) RSFRC, (b) ISFRC.

Source: Own elaboration. 
Based on the requirements specified by EN 14488-5 [15] standard, the toughness of SFRC slabs was calculated for deflections of $5,10,15,20,25$, 30, 35, and $40 \mathrm{~mm}$. Fig. 6 and Table 6 show the results of those deflections for RSFRC and ISFRC. The RSFRC toughness always increases as the dosage of fiber is augmented. However, it is observed in Fig. 6a that the ISFRC toughness for a deflection of $5 \mathrm{~mm}$ decreases as the fiber dosage increases. In the same way, the energy absorption capacity of ISFRC for deflections greater than $10 \mathrm{~mm}$ increases as $V_{F} \times\left(l_{f} / d_{f}\right)$ is augmented, being more significant than that of RSFRC (see Fig. 6b). Fig. 6c also shows an increase in the ISFRC toughness as $V_{f} \times\left(l_{f} / d_{f}\right)$ is augmented. Fig. $6 \mathrm{~d}$ shows that ISFRC with a $D_{f}$ of $65.2 \mathrm{~kg} / \mathrm{m}^{3}$ reaches a toughness of up to $800 \mathrm{~J}$ at a $20 \mathrm{~mm}$ deflection, which is $6 \%$ higher than the toughness obtained for RSFRC.
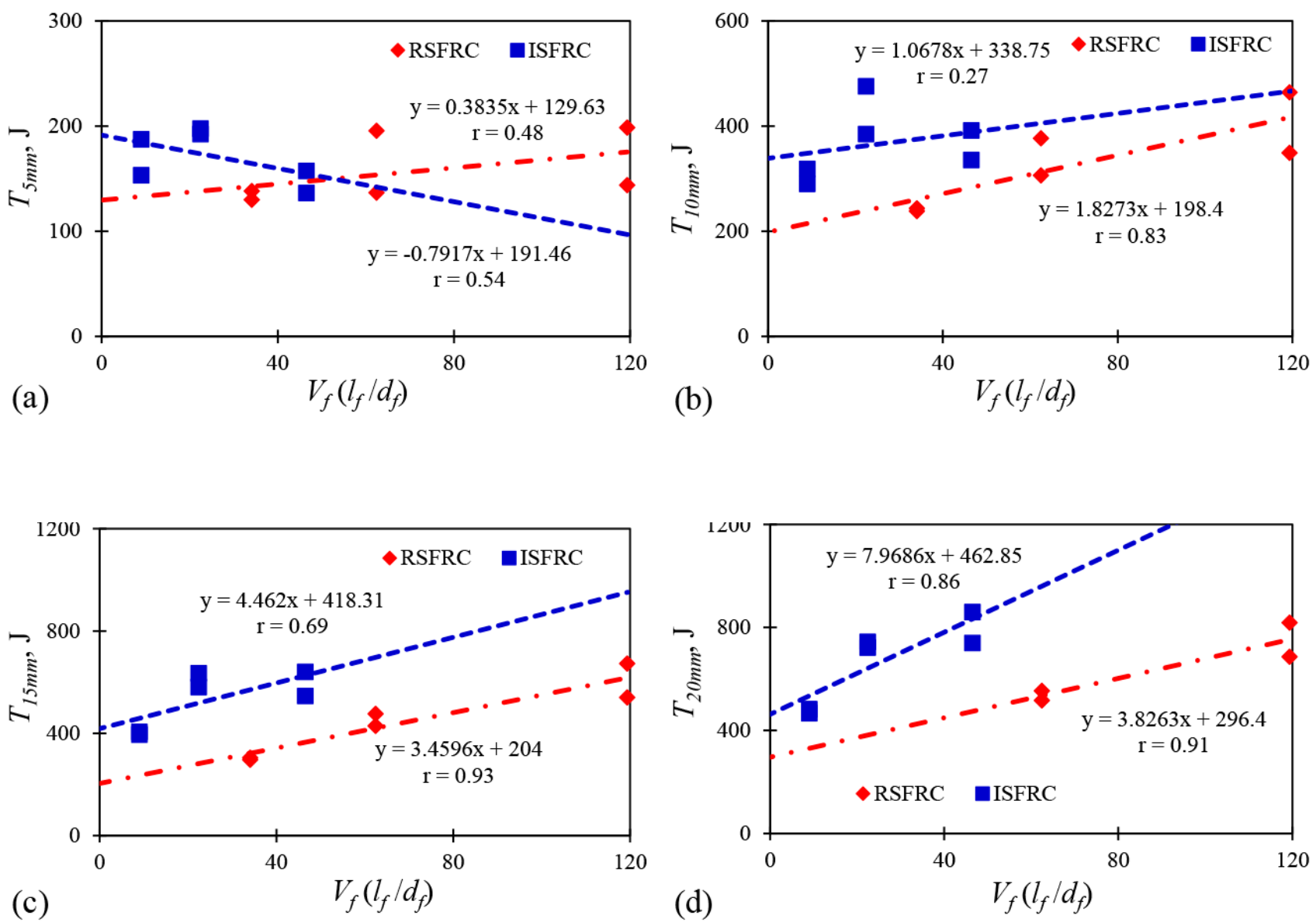

Fig. 6. Flexural toughness for PC, RSFRC, and ISFRC slabs: (a) $T 5 \mathrm{~mm}$, (b) $T 10 \mathrm{~mm}$, (c) $T 15 \mathrm{~mm}$, (d) $T 20 \mathrm{~mm}$. Source: Own elaboration. 
Table 6. Toughness of Concrete Slabs for Different Deflections

\begin{tabular}{|c|c|c|c|c|c|c|c|}
\hline \multirow{2}{*}{$\begin{array}{l}\text { Type of } \\
\text { Concrete } \\
D_{f}- \\
\text { measured, } \\
\mathrm{kg} / \mathrm{m}^{3}\end{array}$} & \multirow[b]{2}{*}{$\begin{array}{l}\text { Statistical } \\
\text { Parameter }\end{array}$} & \multicolumn{3}{|l|}{ ISFRC } & \multicolumn{3}{|l|}{ RSFRC } \\
\hline & & 12.7 & 31.5 & 65.2 & 18.6 & 34.0 & 65.1 \\
\hline \multirow{2}{*}{$T_{5 \mathrm{~mm}} \mathrm{~J}$} & $x$ & 170.6 & 195.2 & 147.0 & 134.3 & 166.2 & 171.2 \\
\hline & $\mathrm{CV}, \%$ & 14.2 & 1.9 & 10.1 & 4.4 & 25.1 & 22.6 \\
\hline \multirow{2}{*}{$T_{10 \mathrm{~mm}} \mathrm{~J}$} & $x$ & 304.7 & 430.7 & 364.0 & 241.2 & 341.7 & 406.8 \\
\hline & $\mathrm{CV}, \%$ & 6.6 & 14.9 & 11.0 & 1.5 & 14.6 & 20.0 \\
\hline \multirow{2}{*}{$T_{15 \mathrm{~mm}} \mathrm{~J}$} & X & 400.6 & 608.1 & 593.5 & 300.3 & 425.3 & 606.1 \\
\hline & $\mathrm{CV}, \%$ & 2.0 & 6.3 & 11.3 & 1.9 & 7.4 & 15.5 \\
\hline \multirow{2}{*}{$T_{20 \mathrm{~mm} \prime} \mathrm{J}$} & X & 475.2 & 733.4 & 800.3 & - & 535.3 & 753.0 \\
\hline & $\mathrm{CV}, \%$ & 2.4 & 2.1 & 10.6 & - & 4.9 & 12.4 \\
\hline \multirow{2}{*}{$T_{25 m m^{\prime}} \mathrm{J}$} & $x$ & 588.7 & 871.8 & 961.8 & - & - & 863.3 \\
\hline & $C V, \%$ & 12.4 & 5.2 & 7.3 & - & - & 10.3 \\
\hline \multirow{2}{*}{$T_{30 \mathrm{~mm} /} \mathrm{J}$} & X & 598.4 & 917.1 & 1103.6 & - & - & - \\
\hline & $\mathrm{CV}, \%$ & 0.5 & 1.3 & 2.5 & - & - & - \\
\hline \multirow{2}{*}{$T_{35 \mathrm{~mm} /} \mathrm{J}$} & $x$ & - & 992.4 & 1209.3 & - & - & - \\
\hline & $\mathrm{CV}, \%$ & - & 2.1 & 0.19 & - & - & - \\
\hline \multirow{2}{*}{$T_{40 \mathrm{~mm}} \mathrm{~J}$} & $x$ & - & - & 1302.0 & - & - & - \\
\hline & $\mathrm{CV}, \%$ & - & - & 2.8 & - & - & - \\
\hline
\end{tabular}

Source: Own elaboration.

\section{Conclusions}

The procedure commonly used to extract recycled steel fibers from waste tires makes it very difficult to obtain regular and rubber-free geometries. It was observed in this study that recycled steel fibers have different lengths and diameters. Also, the attached rubber can hinder the bonding between fibers and concrete. Recycled fibers do not have hooks that improve bonding through mechanical interlocking. In the same way, recycled fibers tend to get entangled when mixed with concrete because of their irregular geometry. However, the use of a superplasticizer to increase concrete slump and workability reduced recycled fiber clusters.
The ISFRC and RSFRC slabs showed similar cracking patterns, although the ISFRC performance was, on average, more significant than that of RSFRC. The geometry of recycled steel fibers did not provide the same binding. One of the advantages of industrial fibers is their hook that allows better anchoring between concrete and reinforcement. In the case of recycled fibers, this hook is not present, and the irregular and variable geometry of the fibers makes it difficult for them to have good concrete interlocking. A possible solution for this could be the hybrid mixture of the two types of steel fibers to achieve better concrete performance. 
Based on trends of experimental data, preliminary equations are practical tools for analysis and design and can predict the mechanical performance of the ISFRC and RSFRC slabs in terms of parameters such as $F_{C}^{\prime}$ and $V_{F} \times\left(l_{f} / d_{f}\right)$. These equations apply to concrete with a compressive strength between 35 $\mathrm{MPa}$ and $42 \mathrm{MPa}$, industrial steel fibers and steel fibers obtained from waste tires, dosages of recycled fibers between 10 and $65 \mathrm{~kg} / \mathrm{m}^{3}$, and values of $V_{f} \times\left(l_{f} / d_{f}\right)$ between 30 and 120 .

\section{ACKNOWLEDGMENTS}

The authors thank the Vicerrectoría de Investigaciones at the Universidad Militar Nueva Granada (UMNG) for financial support of the IMP-ING-2933 Project. The donation of concrete, industrial steel fibers, and recycled steel fiber from Argos-Colombia (Diego Velandia), Bekaert-Colombia (Liliana Cardona), and Grupo Renova, respectively, is greatly appreciated. The authors also thank engineers Sebastián Guzman for their support during data processing. The information contained in this article represents exclusively the opinion of the authors and does not necessarily represent the opinions of the sponsor.

\section{References}

[1] K. Strukara, T. Kalman, I. Miličevićb, and R. Bušićb, "Potential use of rubber as aggregate in structural reinforced concrete element-A review," Eng. Struct., vol. 188, pp. 452-468, 2019, doi: 10.1016/j.engstruct.2019.03.031

[2] S. Wong and S. Ting, "Use of recycled rubber tires in normal and high-strength concretes," ACI Mater. J., vol. 106, no. 4, pp. 325-332, 2009, doi: 10.14359/56652

[3] A. Graeff, K. Pilakoutas, K. Neocleous, M. Vania, and N. Peres, "Fatigue resistance and cracking mechanism of concrete pavements reinforced with recycled steel fibers recovered from post-consumer tires," Eng. Struct., vol. 45, pp. 385-395, 2012, doi: 10.1016/j.engstruct.2012.06.030

[4] O. Sengul, "Mechanical properties of slurry infiltrated fiber concrete produced with waste steel fibers," Constr. Build. Mater., vol. 186, pp. 1082-1091, 2018, doi: 10.1016/j.conbuildmat.2018.08.042
[5] M. Aiello, F. Leuzzi, G. Centonze, and A. Maffezzoli, "Use of steel fibres recovered from waste tyres as reinforcement in concrete: Pull-out behaviour, compressive and flexural strength,"Waste Manag., vol. 29, no. 9, pp. 1960-1970, 2008, doi: 10.1016/j.wasman.2008.12.002

[6] S. Rossli and I. Ibrahim, "Mechanical properties of recycled steel tire fibres in concrete," Fac. Civil Eng., University of Technology, Malaysia, Tech. Rep., 2012.

[7] O. Sengul, "Mechanical behavior of concretes containing waste steel fibers recovered from scrap tires," Constr. Build. Mater., vol. 122, pp. 649-658, 2016, doi: 10.1016/j.conbuildmat.2016.06.113

[8] G. Centonze, M. Leone, and M. Aiello, "Steel fibers from waste tires as reinforcement in concrete: A mechanical characterization," Constr. Build. Mater., vol. 36, pp. 46-57, 2012, doi: 10.1016/j.conbuildmat.2012.04.088

[9] G. Centonze, M. Leone, E. Vasanelli, and M. Aiello, "Interface analysis between steel bars and recycled steel fiber reinforced concrete," in 7th Int. Conf. Fract. Mech. Concr. Concr. Struct. (FraMCoS-8), Toledo, Spain, 2013.

[10] Z. Zamanzadeh, L. Lourenço, and J. Barros, "Recycled steel fibre reinforced concrete failing in bending and in shear," Constr. Build. Mater., vol. 85, no. 15, pp. 195207, 2015, doi: 10.1016/j.conbuildmat.2015.03.070

[11] Building code requirements for structural concrete and commentary, ACI Committee 318, American Concrete Institute (aci), Farmington Hills, usa, 2014.

[12] Colombian Building Code for Earthquake-resistant Construction, nsr-10, Colombian Association of Earthquake Engineering, ais, Colombia, 2010.

[13] J. Guzmán, "Mechanical properties of concrete reinforced with steel fibers recycled from waste tires," B.S. thesis, Universidad Militar Nueva Granada (umng), Colombia, 2016.

[14] Standard test method for static modulus of elasticity and Poisson's ratio of concrete in compression, ASTM C469, ASTM International, West Conshohocken, Pennsylvania, 2014.

[15] Testing sprayed concrete - Part 5: Determination of energy absorption capacity of fibre reinforced slab specimens, en 14488-5, cen European Committee for Standardization, 2006.

[16] State-of-the-art report on fiber reinforced concrete, aci-544.1, American Concrete Institute (aci), usa, 1996.

[17] J. Carrillo and D. Silva, "Flexural tests on concrete slabs-on-ground reinforced with steel fibers," Ing. Investig. Tecnol., vol. 17, no. 3, pp. 317-330, 2016. 